\title{
A Gene Action for Avirulence Partially Affected by Mutation in Rice Blast Fungus***
}

\author{
Hiroshi Fujimaki*, Shigehisa Kiyosawa** \\ and Masao YoKoo** \\ 藤巻 宏*・清沢茂久**・横尾政雄**：イネいもち病菌の突然变異により \\ 部分的に変化した非病原性遺伝子の作用
}

\begin{abstract}
Aggressiveness of a mutant for virulence of rice blast fungus was investigated using isogenic lines of rice which were selected from japonica $\times$ indica crosses for incorporating a gene for blast resistance $P i-z^{t}$. The mutant fungus strain acquired a specific virulence to $P i-z^{t}$, which is resistant to a blast fungus strain Ken 53-33. The mutant blast strain was found to be weaker in aggressiveness on the resistant isolines than on the susceptible ones.

Aggressiveness of three mutant strains isolated from different fungus strains was compared with that of the original strains on five susceptible rice varieties. One of the mutants, Ken 53-33- $z t^{+}$, was less aggressive than the original strain, but the other two mutants were as much aggressive as their parental strains.

These results were discussed in reference to the gene-for-gene theory for hostpathogen interaction.

(Received May 29, 1974)
\end{abstract}

\section{Introduction}

The importance of the use of isogenic lines (or isolines) of crop plants has been increasingly recognized in studying the gene action of a specific locus. Isolines have been used for investigating host-pathogen interactions in several plant diseases ${ }^{1,2,7,11}$.

Lines of cultivated rice, Oryza sativa L., used in the present investigation were highly isogenic except for a locus for blast resistance, $P i-z^{t}$. Strains of blast fungus, Pyricularia oryzae Cav., mainly used here were isolated as mutants for specific virulence to the gene for blast resistance $P i-z^{t 10)}$. Those mutant strains of rice blast fungus were regarded as highly isogenic except for the locus mutated for virulence. In a preliminary test, one of the mutants of blast fungus Ken $53-33-z^{t+}$ was found to be virulent but weaker in aggressiveness to isolines with $P i-z^{t}$ than to those without it. In order to confirm the result and to see how generally the phenomenon exists, the pathogenicity. of the virulent mutant of blast fungus is investigated by the use of rice isolines developed from the two different crosses in the first two experiments.

* Crop Research Division, Central Agricultural Experiment Station, Konosu, Japan. 農林省農事試験場作物部

** Division of Genetics, National Institute of Agricultural Science, Hiratsuka, Japan. 農林省農業技術研究所遺伝科

*** This study was carried out at the National Institute of Agricultural Sciences (Hiratsuka) when the senior author worked there. 
A principle has been disclosed in relation to the stabilizing selection that a new fungus strain occurring through mutation for virulence tended to be less aggressive and lower in fitness than the original strain ${ }^{12}$. To know whether this principle works in the case of rice blast fungus, aggressiveness of three virulent mutants isolated from different blast strains was observed on five susceptible rice varieties in comparison with that of original fungus strains in the last experiment.

\section{Materials and Methods}

Experiments I and II: Isolines of rice were derived from the two japonica $\times$ indica crosses, Norin $8 \times$ TKM. 1 and Morak Sepilai $\times$ Fujisaka 5. TKM. 1 and Morak Sepilai were indica rice varieties and highly resistant to a number of blast fungus strains collected throughout Japan. These two indica varieties were employed as donor parents for blast resistance and the two japonica partners as recurrent parents in the backcross breeding programs. Four backcrosses were repeated to recover agronomic characteristics of respective recurrent parent with successful transfer of blast resistance from donor parent. As illustrated in Fig. 1, four repeated backcrosses were followed by eight time self-pollinations to increase isogeneity of each line.
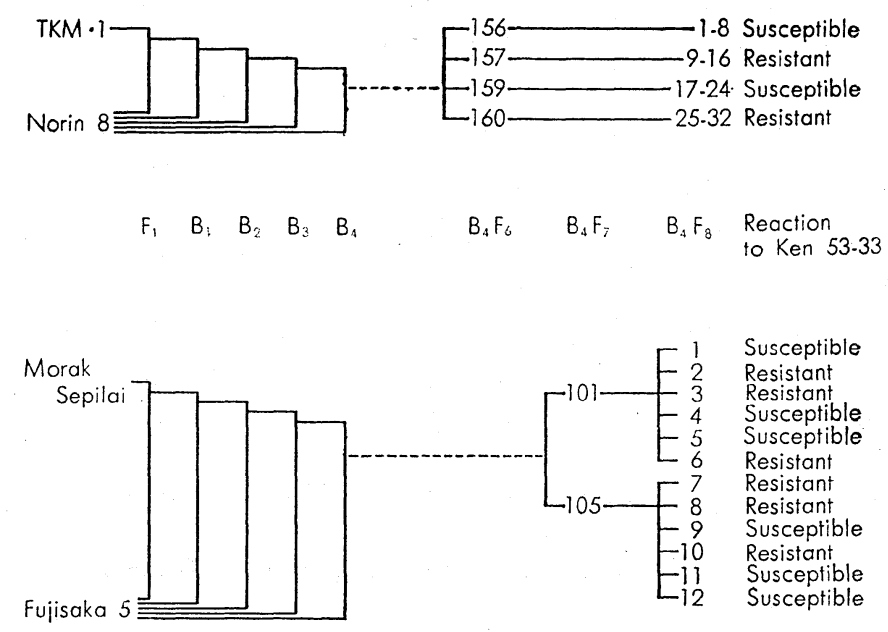

Fig. 1. Isogenic lines except for blast resistance used in the experiments I and II and their resistance reactions to Ken 53-33.

Thirty-two isolines (hereafter refer to NT-isolines) were derived from the cross Norin $8 \times$ TKM. $1 \times$ Norin $8^{4}$. They were derived from four line-groups in the sixth selfing generation. Sixteen isolines in the two line-groups (156 and 159 in Fig. 1) were susceptible but the other sixteen isolines were resistant to the blast fungus strain Ken 53-33. Twelve isolines (refer to MF-isolines) were obtained from the other cross Morak Sepilai $\times$ Fujisaka $5^{5}$. Six of them were susceptible and the others were resistant to Ken 55-33. In the process of selecting the isolines, it was clarified that the resistant isolines in the two crosses carried the identical gene $P i-z^{t}$ for blast resistance ${ }^{4}$.

The virulent mutant strain of blast fungus used in the first two experiments, Ken 53-33- $z t^{+}$, had been isolated from susceptible type lesions appearing when a line carry- 
ing $P i-z^{t}$ was inoculated with Ken $53-33^{10)}$. This mutant strain proved to acquire the specific virulence to rice plant with $P i-z^{t}$. Reactions of parental varieties and isolines are shown in Table 1.

Thirty-two NT-isolines were inoculated with the virulent mutant strain in the first part and with single-spore isolates from the mutant strain in the second and the third parts of the experiment I. The split plot design with three replications was employed in this experiment. Four line-groups were allocated at random to whole plots (boxes) and eight lines in each group to sub-plots (rows in a box) within a whole plot.

Twelve MF-isolines were tested with Ken $53-33-z t^{+}$in the experiment II. The test was repeated with the same plant materials in two seasons. The randomized complete block design was applied to this experiment. The all twelve isolines were

Table 1. Resistance reactions of parental varieties and isogenic lines to Ken 53-33 and its virulent mutant Ken $53-33-z t^{+}$

\begin{tabular}{|c|c|c|c|}
\hline \multirow[b]{2}{*}{ Variety or isogenic lines } & \multirow[b]{2}{*}{ Estimated genotype } & \multicolumn{2}{|c|}{ Reaction to } \\
\hline & & Ken 33-33 & Ken $53-33-z t^{+}$ \\
\hline TKM. 1 & $P i-z^{t}, P i-X$ & $\mathrm{R}^{\mathrm{h}}$ & $\mathrm{R}^{\mathrm{h}}-\mathrm{M}$ \\
\hline Morak Sepilai & $P i-z^{t}, P i-Y$ & $\mathrm{R}^{\mathrm{h}}$ & $\mathrm{M}$ \\
\hline Norin 8 & + & $\mathrm{S}$ & $\mathrm{S}$ \\
\hline Fujisaka 5 & $P i-i$ & $\mathrm{~S}$ & $\mathrm{~S}$ \\
\hline Norin $8 \times$ TKM. $1 \times$ Norin $8^{4}$ & & & \\
\hline Resistant lines & $P i-z^{t}$ & $\mathrm{R}^{\mathrm{h}}$ & $\mathrm{S}$ \\
\hline Susceptible lines & + & $\mathrm{S}$ & $\mathrm{S}$ \\
\hline Morak Sepilai $\times$ Fujisaka $5^{5}$ & & & \\
\hline Resistant lines & $P i-z^{t}, P i-i$ & $\mathrm{R}^{\mathrm{h}}$ & $\mathrm{S}$ \\
\hline Susceptible lines & $P i-i$ & $\mathrm{~S}$ & $\mathrm{~S}$ \\
\hline
\end{tabular}

Note) $P i-X$ and $P i-Y$ represent unidentified genes for blast resistance.

Table 2. Materials used in the experiments I and II

\begin{tabular}{|c|c|c|c|c|}
\hline Experiment & $\begin{array}{l}\text { Crosses from which isogenic } \\
\text { lines were derived }\end{array}$ & $\begin{array}{l}\text { Mutants for } \\
\text { virulence }\end{array}$ & Year \& season & $\begin{array}{l}\text { No. of } \\
\text { isogenic } \\
\text { lines used }\end{array}$ \\
\hline \multicolumn{5}{|l|}{ Experiment I } \\
\hline Part 1 & Norin $8 \times$ TKM. $1 \times$ Norin $8^{4}$ & Ken $53-33-z t^{+}$ & Winter, 1968 & 32 \\
\hline Part 2 & Norin $8 \times$ TKM. $1 \times$ Norin $8^{4}$ & Ken $53-33-z t^{+} \mathrm{a}$ & Winter, 1968 & 32 \\
\hline Part 3 & Norin $8 \times$ TKM. $1 \times$ Norin $8^{4}$ & Ken $53-33-z t^{+} \mathrm{b}$ & Winter, 1968 & 32 \\
\hline \multicolumn{5}{|l|}{ Experiment II } \\
\hline Part 1 & Morak Sepilai $\times$ Fujisaka $5^{5}$ & Ken $53-33-z t^{+}$ & Winter, 1973 & 12 \\
\hline Part 2 & Morak Sepilai $\times$ Fujisaka $5^{5}$ & Ken $53-33-z t^{+}$ & Spring, 1973 & 12 \\
\hline
\end{tabular}

Note) The virulent mutants were isolated by the following procedure,

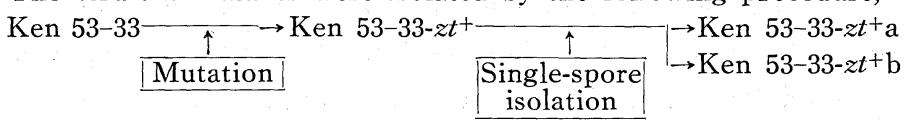


randomly arranged in each of ten boxes and two sets each consisting of five boxes were used for inoculation in two consecutive days.

The materials and the seasons in the two experiments are presented in Table 2. Rice seeds were sown on the upland soil packed in wooden boxes. Seedlings were grown in the greenhouse where air temperature was regulated not to get below $20 \mathrm{C}$. When seedlings grew to the 5 to 6 leaf stage including an incomplete leaf, the suspension of $2 \times 10^{5}$ spores $/ \mathrm{ml}$ of blast fungus was sprayed with Tween 20 as a wetting agent. The rice seedlings were held in the incubation room with air temperature kept around $28 \mathrm{C}$ and nearly saturated humidity for 24 hours. Then they were brought back to the greenhouse. One week after inoculation, susceptible type lesions appearing on the central $3 \mathrm{~cm}$-long part of a leaf expanding at the time of inoculation were counted on ten plants in each line. Mean numbers of susceptible type lesions for a line were used as data for the analysis of variance.

Experiment III : Five susceptible rice varieties, Norin 6, Norin 8, Norin 22, Ginga and $K 50$, which were regarded as different in field resistance and three mutant fungus strain, Ken $53-33-z t^{+}$, Ina $168-z t^{+}$and Ken $54-20-z t^{+}$, as well as their original strains were used in this experiment. The last two mutant strains were isolated by one of the present authors and the first one by the other workers ${ }^{10}$. All the three mutant fungus strains acquired the specific virulence to rice plants carrying $P i-z^{t}$.

Five varieties were planted at random in a wooden box. Each variety occupied two rows. Different fungus strains were allocated to different boxes with two replications. Then twelve boxes (six fungus strains with two replications constituted each part of the experiment. The experiment III consisted of three repeating parts using the same plant materials and design of experiment. In this design of experiment, the differences among boxes were confounded with the effects of fungus strains. Actually as far as the numbers of lesions were concerned, however, the differences among varieties in a box were greater than those among boxes. For this reason, the effects caused by the differences among boxes were reasonably neglected.

The methods of growing plant materials and of inoculation were similar to those in the first two experiments, except that the concentration of spore suspension was $3 \times 10^{4}$ spores $/ \mathrm{ml}$. A week after inoculation the lesions formed on the youngest leaf at the time of inoculation were observed and classified into four types according to their shape and size; b (resistant), bg (moderately resistant), bG (moderately susceptible) and pG (susceptible) and the number of lesions in each type was counted. Indices for pathogenicity of fungus strains were computed by the use of the formula $b+10 \mathrm{bg}+$ $30 \mathrm{bG}+40 \mathrm{pG}$ where the letters indicated the number of lesions of respective types. Average indices for 34 plants (each 17 plants from two rows in a box) were used as basic data for the analysis of variance.

\section{Results}

Experiment I: Average numbers of susceptible type lesions appearing on the NTisolines are presented in Table 3 , and the results obtained from the analysis of variance in Table 4. The numbers of susceptible type lesions appearing on the isolines with $P i-z^{t}$ were significantly less than those on the isolines without it. 
Experiment II: The experimental results obtained by inoculating the MF-isolines with Ken $53-33-z t^{+}$are summarized in Table 5, and the results of the variance analysis are shown in Table 6 . The number of susceptible type lesions were far less on isolines with $P i-z^{t}$ than on those without it. The similar trend was recognized in the two repeating parts of this experiment.

Experiment III : Pathogenicity indices over five varieties are presented in Table 7

Table 3. The numbers of susceptible type lesions appearing on the isogenic lines derived from the cross Norin $8 \times$ TKM. $1 \times$ Norin $8^{4}$ (Experiment I)

\begin{tabular}{|c|c|c|c|c|c|c|}
\hline \multirow{3}{*}{ Reaction to Ken $53-33$} & \multicolumn{6}{|c|}{ No. of susceptible lesions when inoculated with } \\
\hline & \multicolumn{2}{|c|}{ Ken $53-33-z t^{+}$} & \multicolumn{2}{|c|}{ Ken $53-33-z t^{+} \mathrm{a}$} & \multicolumn{2}{|c|}{ Ken $53-33-z t^{+} \mathrm{b}$} \\
\hline & Mean & Difference & Mean & Difference & Mean & Difference \\
\hline \multirow[t]{2}{*}{ Susceptible } & 4.99 & & 4.24 & & 4.95 & \\
\hline & & $3.74^{* *}$ & & $2.78^{* *}$ & 1.45 & $3.50 * *$ \\
\hline Resistant & 1.25 & & 1.46 & & & \\
\hline
\end{tabular}

Note) **: Statistically significant at the $1 \%$ level.

The figures in the table show the means of observed numbers of lesions per plant.

Table 4. Analyses of variance for the numbers of susceptible type lesions when the isogenic lines of Norin $8 \times$ TKM. $1 \times$ Norin $8^{4}$ were inoculated with the virulent mutant (Experiment I)

\begin{tabular}{l|c|ccc}
\hline Source of variation & $\begin{array}{c}\text { Degree of } \\
\text { freedom }\end{array}$ & Part 1 & Part 2 & Part 3 \\
\cline { 3 - 5 } & 3 & $114.34^{* *}$ & $88.39^{* *}$ & $98.00^{* *}$ \\
Line groups & 1 & $335.48^{* *}$ & $186.71^{* *}$ & $293.62^{* *}$ \\
Between resistant and $\quad \begin{array}{c}\text { susceptible groups } \\
\text { Within resistant group }\end{array}$ & 1 & 0.92 & 0.01 & 0.02 \\
Within susceptible group & 1 & 6.63 & $78.44^{* *}$ & 0.35 \\
Replication & 2 & 3.28 & 17.91 & 11.38 \\
Error I & 6 & 5.37 & 4.04 & 2.69 \\
Lines in group & 28 & 4.32 & $2.55^{*}$ & 1.86 \\
Error II & 56 & 3.98 & 1.35 & 2.29 \\
\hline
\end{tabular}

Note) * and **: Statistically significant at the $5 \%$ and the $1 \%$ levels, respectively.

Table 5. The numbers of susceptible type lesions appearing on the isogenic lines derived from the cross Morak Sepilai $\times$ Fujisaka $5^{5}$ (Experiment II)

\begin{tabular}{|c|c|c|c|c|}
\hline \multirow{3}{*}{ Reaction to Ken 53-33 } & \multirow{2}{*}{\multicolumn{4}{|c|}{$\begin{array}{c}\text { No. of susceptible lesions when inoculated with Ken } 53-33-z t^{+} \\
\text {Part } 1\end{array}$}} \\
\hline & & & & \\
\hline & Mean & Difference & Mean & Difference \\
\hline \multirow[t]{2}{*}{ Susceptible } & 6.84 & & 6.53 & \\
\hline & & $4.77 * *$ & & $4.28^{* *}$ \\
\hline Resistant & 2.07 & & 2.25 & \\
\hline
\end{tabular}

Note) **: Statistically significant at the $1 \%$ level.

The figures in the table show the means of observed numbers of leisons per plant. 
Table 6. Analysis of variance for the numbers of susceptible lesions when the isogenic lines of Morak Sepilai $\times$ Fujisaka $5^{5}$ were inoculated with the virulent mutant (Experiment II)

\begin{tabular}{l|c|cc}
\hline \hline Source of variation & $\begin{array}{c}\text { Degree of } \\
\text { freedom }\end{array}$ & Part 1 & Part 2 \\
\cline { 2 - 3 } Lines & 11 & $41.92^{* *}$ & $31.15^{* *}$ \\
Line groups (LG) & 1 & 1.56 & 0.66 \\
Between resistant and & 1 & $410.89^{* *}$ & $318.78^{* *}$ \\
susceptible groups (BG) & 1 & 0.18 & 1.20 \\
Witeraction (LG) BG) & 4 & 1.35 & 0.39 \\
Within resistant group & 4 & 10.52 & 5.10 \\
Replications & 5 & 12.52 & $14.37^{* *}$ \\
Inoculation dates & 1 & $37.27^{*}$ & $47.53^{* *}$ \\
Replication in date & 4 & 6.33 & 6.01 \\
Error & 55 & 6.02 & 3.54 \\
\hline
\end{tabular}

Note) $*$ and $* *$ : Statistically significant at the $5 \%$ and the $1 \%$ levels, respectively.

Table 7. The numbers of lesions appearing on the susceptible vareities when inoculated with the three fungus strains and their mutants for virulence (Experiment III)

\begin{tabular}{|c|c|c|c|c|c|c|}
\hline \multirow{2}{*}{ Fungus strain } & \multicolumn{2}{|c|}{ Part 1} & \multicolumn{2}{|c|}{ Part 2} & \multicolumn{2}{|c|}{ Part 3} \\
\hline & Mean & Difference & Mean & Difference & Mean & Difference \\
\hline \multirow[t]{2}{*}{ Ken 53-33 } & 60.9 & & 162.7 & & 102.7 & \\
\hline & & 7.2 & & $95.3^{*}$ & & $73.3^{* *}$ \\
\hline Ken $53-33-z t^{+}$ & 53.7 & & 67.4 & & 29.4 & \\
\hline \multirow[t]{2}{*}{ Ina 168} & 162.6 & & 142.6 & & 36.2 & \\
\hline & & 53.1 & & -8.3 & & 7.6 \\
\hline Ina $168-z t^{+}$ & 109.5 & & 150.9 & & 28.6 & \\
\hline \multirow[t]{2}{*}{ Ken $54-20$} & 143.9 & & 79.1 & & 54.2 & \\
\hline & & -32.4 & & -34.1 & & -40.2 \\
\hline Ken $54-20-z t^{+}$ & 176.3 & & 113.2 & & 94.4 & \\
\hline
\end{tabular}

Note) $*$ and $* *$ : Statistically significant at the $5 \%$ and the $1 \%$ levels, respectively. The figures in the table indicate means of indices over five susceptible varieties culculated by the use of the following formula for each plant. $b+10 b g+30 b G+40 p G$, where b, bg, bG and pG represent numbers of lesions of resistant, moderately resistant, moderately suscesptible and susceptible types, respectively.

to compare the aggressiveness of each original fungus strain with that of the mutated one. Only in the case of Ken 53-33, the original fungus strain gave greater indices than the mutant strain in two out of three repeating parts of the experiment. No significant differences were observed in the other two fungus strains in any repeating part. These indicated that the mutant strain derived from Ken 53-33 was less aggressive than the original strain, while the mutants isolated from the other two fungus strains were as much aggressive as the original ones. 


\section{Discussion}

The importance of the use of isolines in investigating the host-pathogen interaction has been suggested by several workers ${ }^{1,2,7,11)}$. The accuracy of this kind of experiment depends upon the isogeneity of host plants. According to the theoretical calculation ${ }^{6}$, the heterozygous linkage block around the locus held heterozygous can be shorter than five centimorgan after four backcrosses followed by seven self-pollinations. Then the effect of the linkage block around the locus on blast resistance is regarded as almost negligible. Concerning the other independent loci, the possibility to attain homozygosity after eleven inbreeding generations is as high as 0.9995 . In this sense, the isolines of rice plant used in the present study are expected to be extremely isogenic except for the locus affecting blast resistance.

Mutants for virulence of blast fungus had been isolated from susceptible type lesions which rarely appeared on rice plants with the resistance gene $P i-z^{t}$. The mutant strains may be highly isogenic to the original fungus strains except for the single avirulence locus $A v-z t$. These isogenic strains of blast fungus as well as isolines of rice plant are appropriate materials for investigating host-pathogen interactions on the gene-for-gene basis.

In the first experiment, using a set of isolines derived from the cross Norin $8 \times$ TKM. $1 \times$ Norin $8^{4}$, the numbers of susceptible type lesions formed by the mutant fungus strain were found to be less on the lines with $P i-z^{t}$ than on those without it. The second and the third parts of the experiment using single-spore isolates of the mutant strain were carried out to test the possibility that the reduction in numbers of susceptible type lesions on the isolines carrying $P i-z^{t}$ might be caused by the contamination with an avirulent fungus strain and this possibility was ruled out.

The similar results were obtained in the second experiment using the other set of isolines selected from the different cross Morak Sepilai $\times$ Fujisaka 5 . The resistant lines of this cross were found to carry the gene identical to that of the isolines in the previous cross $^{4}$.

It is considered that the mutated gene $A v-z t^{+}$, which is a virulence allele corresponding to $P i-z,{ }^{t}$ shows a remnant action to the resistance gene, that is, that the avirulence gene $A v-z t$ of blast fungus is partially affected by mutation and changed to an incomplete amorph. According to the gene-for-gene theory in relation to the host-pathogen interaction ${ }^{3,5,8}$, the resistance reaction is induced by the interaction between a gene for resistance in host plant and a corresponding gene for avirulence in pathogen. The original fungus strain Ken $53-33$ is supposed to have an avirulence gene $A v-z t$ corresponding to the resistance gene $P i-z^{t}$ in host plant and to produce some active substances to activate the action of the gene for resistance. The mutant strain Ken 53-33$z t^{+}$is assumed to carry a part of $A v-z t$, which may

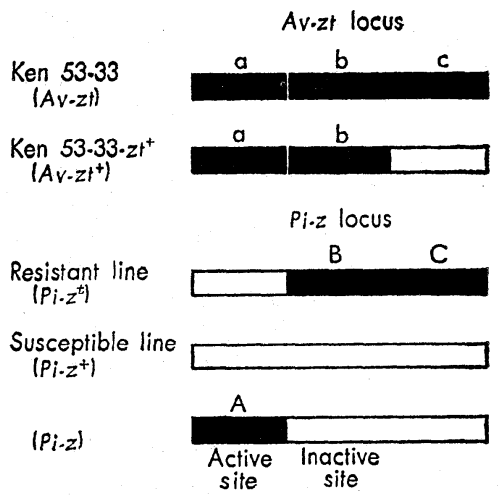

Fig. 2. Proposed semi-fine structures of $A v-z t$ and $P i-z$ loci

Note) It is not clarified whether the ' $a$ ' site may be involved in the $A v-z^{t}$ locus or in another locus. 
produce a substance to activate partially the gene action of $P i-z^{t}$.

It is argued in reference to a semi-fine structural model of genes for resistance and avirulence $^{9)}$ that the avirulence gene $A v-z t$ has at least two active sites, ' $b$ ' and 'c' as shown in Fig. 2. ' $c$ ' might be inactivated by mutation but the other site ' $b$ ' might be remain unaffected. The ' $b$ ' site may be effective to the partial resistance observed in the present investigation. One of the two active sites 'B' of the resistance gene Pi-z $z^{t}$ may interact with the unaffected site ' $b$ ' of the gene for avirulence and the other site ' $\mathrm{C}$ ' with the mutated site ' $\mathrm{c}$ '. The mutant strain Ken $53-33-z t^{+}$is supposed to have the other site ' $a$ ' which interacts with an active site 'A' of the Pi-z locus ${ }^{9}$. But it is not clear whether the site ' $\mathrm{a}$ ' may be involved in the $A v$-zt locus or in another locus.

The third experiment was carried out to know whether blast strains mutated for virulence were generally less aggressive and lower in fitness on rice varieties susceptible to the original strains. The aggressiveness of mutant strains isolated from three different fungus strains was observed in comparison with that of the original ones. But no significant difference is observed between the original and the mutant strains in the two fungus strains. These inconsistent results may be explained by any one of the reasons mentioned below.

1) The aggressiveness of the mutant fungus strain may be affected by the environmental condition under which they are maintained after a single spore isolation.

2) Different loci affecting virulence may be mutated in different fungus strains.

3 ) The mutation may simultaneously occur in the locus (or loci) other than the locus affecting virulence.

It is not determined in the present study which reason mentioned above have related to the inconsistency observed among the different fungus strains.

From the standpoint of rice breeding it was proposed ${ }^{10)}$ that the field resistances of rice varieties with various genes for resistance may well be tested by the use of a blast fungus strain which shows virulence to all those varieties. The fact that a newly occurring mutant of blast fungus may have only a partial virulence to a specific gene for resistance, however, markes it impossible to utilize the mutant fungus strain for testing the field resistance of rice varieties carrying the various genes for resistance.

\section{Literature cited}

1) Briggle, L. W. (1969). Crop Sci. 9: 70-72.

2) Daly, J. M. (1972). Phytopathology $62: 392-400$.

3) Flor, H. H. (1956). Adv. Genet. 8: 29-54.

4) Fujimaki, H. and Yokoo, M. (1971). Japan. J. Breed. 21: 9-12.

5) Hadwiger, L. A. and Schwochau, M. E. (1969). Phytopathology $59: 223-227$.

6) Hanson, W. D. (1959). Genetics $44: 833-837$.

7) Hilu, H. M. (1965). Phytopathology $55: 563-569$.

8) Kiyosawa, S. (1965). Shokubutsu Boeki (Plant Prot.) 19:353-360 (in Japanese).

9) Kiyosawa, S. (1971). Japan. Agr. Res. Quart. $6: 73-80$.

10) Niizeki, H., Iwanaga, Y. and Oono, K. (1973). Basic Studies on Breeding Measures to Counter Explosive Outbreaks of Blast Epidemics in Resistant Rice Varieties. Ministry of Agriculture and Forestry. pp. 91-99. (in Japanese).

11) Moseman, J. G. and Jorgensen, J. H. (1973). Euphytica 22: 189-196.

12) van der Plank, J. E. (1968). Disease Resistance in Plants. Academic Press, N. Y. 


\section{和文摘要}

\section{イネいもち病菌の突然変異により部分的に変化した 非病原性 遺伝子の作用}

藤巻宏・清沢茂久・横尾政雄

イネの indica 品種のいもち病抵抗性遺伝子 $\left(P i-z^{t}\right)$ を厈し交雑法により導入して育成した isogenic 系統 を用いて，この抵抗性遺伝子に対して突然変異により病原性を獲得したいもち病菌系研 53-33- $z t+$ の病原力を 調ベた。その結果，抵抗性遺伝子をもつ系統の上よりももたない系統の上で，この突然変異菌系の病原力が強 く現われることがわかった。

3 つの異なる菌系から別々に分離した突然变異菌系 (いずれもPiz を特異的に侵す菌系) の病原力を感受 性品種の上で原菌系の病原力と比較した。研 53-33- $z t^{+}$だけが原菌系よりも病原力が弱くなっていたが，ほか の 2 つ菌系では病原力に差がなかった。

これらの結果を宿主と寄生者間の働き合いを説明する遺伝子対遺伝子説との関連で論議した。 